\title{
MODEL TOOLS TO ASSESS THE PRODUCTION AND FINANCIAL RELIABILITY OF KNOWLEDGE-INTENSIVE AND HIGH-TECH ENTERPRISES
}
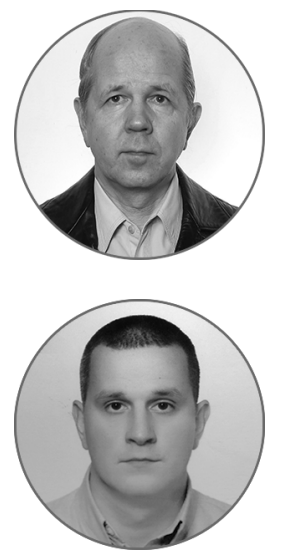

Article history:

Received 3 February 2017

Received in revised form

9 February 2017

Accepted 21 February 2017

Translated 25 May 2017

Available online 15 June 2017

JEL classification: 012, 021, 033

Keywords: reliability,

knowledge-intensive project,

risk, audit, performance evaluation,

expert assessment

\author{
Evgenii Yu. KHRUSTALEV \\ Central Economics and Mathematics Institute of RAS, Moscow, Russian Federation \\ stalev@cemi.rssi.ru \\ Corresponding author
}

Oleg E. KHRUSTALEV

Central Economics and Mathematics Institute of RAS, Moscow, Russian Federation stalev777@yandex.ru

\begin{abstract}
Importance The article considers the problems of evaluating the production and financial reliability of enterprises involved in high-tech project implementation for development and manufacture of innovative products.

Objectives To accelerate progress in the knowledge-intensive and high-technology sphere of production, it is crucial to choose companies with the highest reliability indices as potential performers of innovative projects. It requires new integrated and accurate tools to assess financial-economic and scientific-production reliability of a modern enterprise.

Methods The offered methodology and tools rely on the complex use of modified methods of expert assessment and audit of all corporate operations. We suggest using several indicators of enterprises, for which experts give a clear assessment of their reliability. These indicators are easy to understand and adequately reflect the status of the analyzed company.

Results We developed a method providing precise estimates of reliability even with a limited number of initial data. During the evaluation process, we considered financial, economic, scientific and production components of enterprise's reliability. The proposed models and methods enable to choose the most reliable company to implement innovative projects, to be included into integration structures, and to grant loans.

Conclusions and Relevance The developed methodological approach and model make it possible to integrate quantitative indicators of practical activities of individual company, as well as qualitative indicators of its efficiency from the standpoint of reliability of achieving the targets.
\end{abstract}

The editor-in-charge of this article was Irina M. Komarova

Authorized translation by Irina M. Komarova

\section{Introduction}

The reliability of knowledge-intensive and high-tech enterprises implementing various innovative projects is one of the most important components of risk associated with production technology and S\&T.
Many publications review the various methodological and theoretical issues of managing production and financial risk that arise in various segments of the market economy [1, 2]. Researchers also address practical issues of investment projects and propose 
mechanisms and mathematical tools to implement complex innovative projects for manufacturing products with a long life-cycle and choose the most promising strategy for their manufacturing $[3,4]$.

Considering the scientific and practical novelty and relevance, we should mention techniques used to evaluate the financial and economic reliability of methods for reorganizing the knowledge-intensive and high-tech industry. The techniques make the institutional processes more secure $[5,6]$ and consider the specifics of public project risks $[7,8]$.

We should also emphasize findings of researches that analyze the existing methods and models, which would comprehensively and systemically integrate the risk assessment into the process of evaluating financial and production sustainability of enterprises with various legal and business structure ${ }^{1}$. Higher reliability and efficiency of managerial decisions require to determine the main sources of information and mechanisms for using it $[9,10]$.

When choosing a contractor, the available information on the contractor's reliability enables customers to engage only those enterprises that, under all equal terms, demonstrate the best reliability. Such information also contributes to creating an optimal and fair model of the contractual project value $[11,12]$.

However, the above methods and approaches are not designated to evaluate the enterprise's reliability on the integrated basis and consider all estimates and assessments made by experts majoring in quality, performance and feasibility of various types of activities. We should note that, when the reliability of knowledge-intensive and high-tech enterprises is evaluated, the consistency principle (comprehensiveness) implies that the strategies, programs and plans for developing knowledge-intensive and high-tech production will be properly feasible only if the effective system of respective models, methods and contemporary organizational and economic mechanisms are in place.

\footnotetext{
${ }^{1}$ Endovitskii D.A., Lyubushin N.P., Babicheva N.E. Finansovyi analiz [Financial analysis]. Moscow, KnoRus Publ., 2016, 300 p.; Lyubushin N.P., Babicheva N.E., Kozlova L.V. [Considering the risk factor in analyzing the borrower's creditworthiness]. Ekonomicheskii analiz: teoriya i praktika = Economic Analysis: Theory and Practice, 2011, no. 10, pp. 2-7. (In Russ.); Lyubushin N.P. Kompleksnyi ekonomicheskii analiz khozyaistvennoi deyatel'nosti [Comprehensive economic analysis of business operations]. Moscow, YUNITI-DANA Publ., 2005, 445 p.
}

Consideration must be given to the fact that many scientific and practical tools have already been devised and put into practice so to address some other tasks for increasing the economic and technological security of the society and the State. Therefore, researchers are to identify effective institutional tools, which would be practicable to attain specific goals, outline proposals for the modification of the tools.

Each particular enterprise should be evaluated byconsidering and analyzing descriptors of the economic security and financial sustainability of the knowledge-intensive and high-tech enterprises, which are involved in the implementation of production plans. Researchers usually rely on the enterprise's indicators of research and development, technologies, finance, economy and business operations [13]. Currently, practical methods for evaluating the performance of knowledge-intensive and high-tech enterprises employ several types of models, which more often include probabilistic (like the Altman model), rating-based and auditing ones.

\section{Reliability Evaluation Models and Tools}

For the recent years, many Russian and foreign scholars have delved into various aspects of identifying and assessing risks that arise from production and financial operations of knowledge-intensive and high-tech enterprises, and methods for mitigating, eliminating and preventing those risks [14-16].

We should spotlight methods for evaluating the competitiveness of a knowledge-intensive and high-tech enterprise since they reflect the enterprise's production and financial reliability [17]; tools for analyzing enterprises contracted for project implementation during the preliminary evaluation through mathematical modeling, information and analytical systems for screening production capabilities, and reliability of enterprises contracted for project implementation during the preliminary assessment and identification of risks associated with a project assignment to be performed at the enterprise's facilities [18].

To reasonably select project enterprises in line with an analysis of the production, financial, economic and performance reliability and the level of related risks, those who perform the selection use methods, which determine the project contractors on the basis of the fuzzy preference relation, and neural fuzzy networks. Neural fuzzy networks focus 
on the competitive environment and respective problems.

It ought to be mentioned that probabilistic, rating-based and auditing models for reliability evaluation became most popular. Their advantages and disadvantages should be examined in more detail.

Probabilistic model, or the Altman Model [19] relies upon the discriminant function based on the discriminant analysis and synthesis in relation to the sample and evaluation of corporations. This analysis pursues accumulating statistical data on the sample of corporations and setting up a discriminant function dividing all the enterprises in question into groups with an identical financial position. If the enterprise in question is attributable to a certain group, the customer may make judgments on the financial security and reliability of the enterprise. Parameters of the discriminant function are set using the statistical method for processing of data on the specific sample of enterprises.

Relying upon a discriminant analysis and synthesis to build the sample of enterprises, Edward Altman set up the discriminant function $A L T$ below:

$$
\begin{aligned}
& A L T=1.2 Y_{1}+1.4 Y_{2}+3.3 Y_{3}+0.64 Y_{4}+1.05_{5}
\end{aligned}
$$

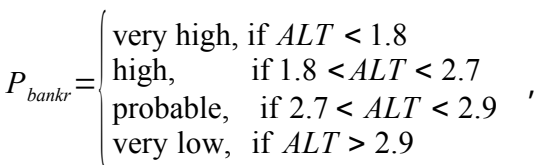

where $Y_{1}$ is the ratio of the enterprise's current assets to total assets;

$Y_{2}$ is the ratio of reinvested but retained earnings to total assets of the enterprise;

$Y_{3}$ is the ratio of the enterprise's earnings before interests and taxes (EBID) to total assets;

$Y_{4}$ is the ratio of the cost of capital in the market economy to borrowings;

$Y_{5}$ is the ratio of revenue from sale of products to total assets;

$P_{\text {bankr }}$ stands for the bankruptcy probability of the enterprise.

This model is limited in use for setting up and performing production plans, since the discriminant analysis may respond to type-specific distinctions. Therefore, each particular type of activity requires to select a new sample of enterprises and, subsequently, a new discriminant function.

Rating-Based Model. The model for rating-based and comparative evaluation of business opportunities and performance of the enterprise, profitability and financial position usually envisages the following main steps [20]:

- collection and analytical processing of source data for the time period in question;

- substantiation of a set of criteria and indicators intended for rating-based evaluation of business opportunities and the enterprise's performance, profitability and financial position, their detailed classification and determination of the integrated criterion (indicator) of the rating-based evaluation;

- arrangement (ranking) of all analyzable enterprises by rating.

The final algorithm for rating-based evaluation provides for five consecutive steps, comparing business opportunities and performance, profitability and the financial position of the enterprise:

1) source data are presented as the $a_{i j}$ matrix, where lines enumerate indicators, like $i=1,2,3, \ldots, n$, and columns indicate numbers of enterprises to be compared $(j=1,2,3, \ldots, m)$;

2) the maximum value is assessed for each indicator, being put into the matrix column and describing the model conditional enterprise $(m+1)$;

3) each source item of the $a_{i j}$ matrix changes in accordance with the following formula:

$$
x_{i j}=\frac{a_{i j}}{\max _{j}},
$$

where $x_{i j}$ means new standardized indicators of financial, economic and production conditions of the $j$-enterprise;

4) the proposed formula is used to assess the rating of each enterprise under study:

$$
R_{j}=\sqrt{K_{1} x_{1 j}{ }^{2}+K_{2} x_{2 j}{ }^{2}+\ldots+K_{n} x_{n j}{ }^{2}},
$$

where $R_{j}$ is the final rating of the $j$-enterprise;

$K_{i}$ refers to weight coefficients of each $i$-indicator;

5) all analyzable enterprises are ranked (arranged) in a sequence as their rating declines. The highest 
rating shall be assigned to the enterprise with the lowest $R$.

In fact, enterprises treat the information on production, financial and economic performance as very confidential, especially in planning, due to legal changes in the status (corporatization, complete or partial privatization, etc.) and growing competition. Thus, planners usually rely upon very limited information on principal indicators of production, financial and economic activities of enterprises.

\section{Comprehensive Method (Toolkit) Based on Audit Results and Expert Assessments}

To evaluate the reliability of knowledge-intensive and high-tech enterprises performing knowledge-intensive innovative projects, we devise a method, which allows to unambiguously and accurately evaluate the reliability of enterprises, notwithstanding limited information on financial, production and other aspects of performance. As part of the method, we comprehensively apply modified (improved) techniques for auditing and expert assessment of various types of corporate activities. However, the auditing technique may be used separately if information needed for financial reliability evaluation is available.

Independent audit of productive, financial and economic activities is the most unbiased and appropriate way to evaluate the reliability of the knowledge-intensive and high-tech enterprise. Contemporary auditing practices constitute accounting control, financial analysis and revision of all types of activities, which autonomous groups of professionals carry out at the enterprise.

Audit pursues not only examination and evaluation of the financial and economic position of the knowledge-intensive and high-tech enterprise and thorough check of all financial statements and accounting records, but also assess earnings per the enterprise's shares, profitability, solvency, financial sustainability, turnover, capital-to-labor ratio and productivity. Standard and ordinary forms of financial reporting are sources of information needed to perform any audit.

As for indicators that have the strongest effect on the sustainability of the knowledge-intensive and high-tech enterprise, we should point out solvency, economic sustainability, capital-to-labor ratio, condition of fixed assets and funds.
The enterprise's reliability can be accurately evaluated using the specific weight of financial investment in assets, which shape research, production and economic capabilities. Assets reflecting the quality and the value of the enterprise's potential are specified as total residual value of all fixed assets. The specific weight of financial investment in research and production assets $(B U)$ is assessed indeed as the ratio of production assets $(A P)$ to total funds of the enterprise $(C P)$ :

$B U=A P / C P$.

The general condition of all fixed assets can be described with the depreciation coefficient $(K I)$ calculated as follows:

$\mathrm{KI}=\mathrm{Cl} / \mathrm{CH}$

where $\mathrm{Cl}$ is the sum of depreciation charged on all fixed assets;

$\mathrm{CH}$ is the initial cost of all available fixed assets.

The capital-to-labor ratio $F$ characterizes what percentage of the value of fixed assets is attributable to one employee. This indicator is expressed with the following formula:

$F=C H / Y$,

where $\mathrm{CH}$ is the initial cost of fixed assets;

$Y$ is the average headcount.

To calculate the capital-to-labor ratio $K F$, we should set up rates of $F$ against the average capital-to-labor ratio of knowledge-intensive and high-tech enterprises with similar specialization $F C$ :

$K F=F / F C=C H \cdot F C / Y$.

In the early 1990s, the ratios below were applied as corporate solvency criteria:

- absolute liquid ratio assessed as the ratio of cash and short-term financial investment to current liabilities of the enterprise;

- interim current ratio assessed as the ratio of cash, receivables and short-term financial investment to current liabilities;

- total current ratio assessed as the ratio of current assets to current liabilities.

When the structure and value of current assets sharply changes in various periods of corporate operations, 
solvency criteria become impossible to estimate using the interim current ratio and absolute liquid ratio.

To ascertain the enterprise's insolvency, we accepted two additional financial indicators, i.e. the current liquidity ratio $K T L$ that should be more than or equal to 2, and the working capital to current assets ratio KOSOS that should be more than 0.1. Although these insolvency indicias were abolished in $2003^{2}$, they are still in use when it comes to the insolvency testing. The bankruptcy criterion was also modified indeed. The enterprise's insolvency is gauged by the ability to pay.

Currently, the ratio of short-term borrowings (current liabilities) to average monthly revenue KPTO is expressed with the following formula:

$K P T O=T Z S / S V$,

where TZS is current liabilities of the enterprise (current borrowings);

$S V$ is the average gross revenue of the enterprise.

For knowledge-intensive and high-tech enterprises of special strategic importance for the national economy, the KPTO ratio should not exceed 6.

To evaluate the solvency, it is reasonable to compare general and factual current ratios. Total current ratio $O K P$ is expressed with the following formula:

$O K P=(M O C+D Z+D C) / K Z$,

where $M O C$ is the amount of current tangible assets;

$D Z$ is accounts receivable;

$D C$ is short-term financial investment and cash;

$K Z$ is current liabilities.

Assessed this way, the ratio is applied by comparing it with the general current ratio NOKP that is typical of the enterprise. The NOKP ratio is assessed as follows:

$N O K P=(M O C D+B D Z+K Z) / K Z$,

where MOCD is the amount of current tangible assets in accordance with the presumed contract;

$B D Z$ is bad debts.

The enterprise's sustainability, if viewed through all the proposed indicators, can be assessed

\footnotetext{
${ }^{2}$ Resolution of the RF Government On Rules for Claiming Obligations to the Russian Federation in Bankruptcy Cases and Bankruptcy Proceedings of April 15, 2003 № 218.
}

by compressing them. Thus, we should use traditional tools for a multicriteria compression.

Another method for summarizing the criteria can be used, without applying mathematical tools. It requires to verify the condition of KPTO $=T Z S / S V$. If it is not verified, the enterprise's reliability is determined with the $K_{n}$ indicator:

$K_{n}=K P \cdot O K P / N O K P$,

where $K P$ is an empirical coefficient, which stands for the decision-maker's attitude to the risk (0.1 for absolute absence of risk, 0.9 for high risk exposure).

If the condition is verified, other indicators should be taken into account.

Using the depreciation coefficient of fixed assets and the capital-to-labor ratio, we can construct a combined indicator - the capital-to-labor ratio adjusted for depreciation of all fixed assets KFI:

$$
K F I=(1-K I) K F=\frac{\left(1-\frac{C I}{C H}\right) C H}{Y \cdot F C} .
$$

The next step is an analysis of $B U$ and $K F I$ indicators.

The decision matrix method is widely used in foreign practices for analyzing production and financial activities of the knowledge-intensive and high-tech enterprise, and solving similar tasks.

Therefore, the enterprise's reliability can be quite accurately assessed using the proposed method that prescribes consecutive formalized procedures, and using standard financial reporting and accounting documents, which the enterprise normally prepares.

\section{Comprehensive Evaluation of the Enterprise's Reliability}

Based on the proposed method for expert assessment of the reliability of the knowledge-intensive and high-tech enterprise, we can conduct a comprehensive evaluation. The following steps should be completed herein. Based on the evaluation results and analysis of heterogeneous data generated as a result of examination and audit, it is necessary to assess the real reliability of the enterprise in question so to decide whether it is scientifically reasonable to involve it into the performance of an innovative project. 
Measurement scales of the corporate reliability are what makes results of expert assessment of the enterprise formally different from its production and financial reporting.

For data processing, we suggest using the following scientific and methodological approach based on the mathematical economics theory. We set a cumulative distribution function of nonparametric type:

$$
p^{v}(x)=\frac{n_{1}^{v}(z)}{n},
$$

where $n_{1}^{v}$ is the number of enterprises, where the $v$-indicator does not make them better than the $z$-indicator;

$z$ is the amount that equals the absolute value of the $v$-indicator or the rank;

$n$ is the total number of analyzable enterprises.

The frequency of the event is expressed as $p^{v}(z)$.

To unify the scales, sometimes it is reasonable to substitute the absolute scale with the interval one, with ordinal numbers of intervals being considered as ranks (Fig. 1). Then the processing becomes unified. If the number of ranks increases, the accuracy of assessing the enterprises' reliability by enumerating and comparing their qualities ceases to depend on the way source data are presented, and tends to the same extreme value.

Where there are only two classes, that is, the measurement scale is binary, and the enterprise is attributable to class 0 , its reliability is estimated as $n_{0} /\left(n_{0}+n_{1}\right)$, where $n_{0}$ and $n_{1}$ represent the number of items pertaining to class 0 and class 1 . If the enterprise is in class 1 , its reliability is equated to 1 .

When there are three values in the measurement scale, the enterprise's reliability is expressed as $n_{0} /\left(n_{0}+n_{1}+n_{2}\right)$ if it is in class 0 , and $k_{\mathrm{H}}=\left(n_{0}+n_{1}\right) /\left(n_{0}+n_{1}+n_{2}\right)$ if it is in class 1 . The reliability is equal to 1 if the enterprise is attributable to class 2 .

Should any information be missing, reliability indicators are measured with the binary scale. In collecting additional or more detailed information, it is necessary to increase the number of grades.

The situation gets especially favorable when the reliability indicator is quantified. In this case, indicators for the analyzable group of enterprises are arranged as they rise and allocated into the necessary number of groups (4-6). Enterprises in Group 1 (the lowest reliability) do not receive any points for his indicator, the following group receives one point, and the others are treated likewise.

The proposed indicator has physical significance as follows:

- when the enterprise has the highest score for all indicators, its reliability is 1 ;

- when the enterprise is definitely worse than others for at least one indicator, its reliability is zero;

- when the enterprise has the highest score for all the indicators, but it fails to catch up with $F$ of enterprises, then the reliability of this enterprise is assessed as $1-(F /(n-1))$, and the worst score is of defining significance.

\section{Conclusions}

The proposed model and methodological approach allow to evaluate the reliability of enterprises within the analyzable population of random size as accurately as possible. They also help to integrate qualitative assessments of independent experts on corporate performance in terms of reliability and efficiency of its participation in a certain innovative project, and numerous quantitative indicators of research, production, financial, economic and business activities, which are evaluated as part of an independent audit. In this case, the integral condition of the enterprise is reflected with a vector in the space of phase coordinates represented with quantitative and qualitative indicators. As the principal advantage and strength of the proposed methodological framework, we should mention that it enables to determine the enterprise's reliability even if there are few phase coordinates (for example, for two coordinates) and the relevant information is scare or confidential. As a result, it helps the customer substantiate, in terms of quality and quantity, the choice and selection of enterprises, that have the highest indicators of production and financial reliability, for performing the customer's innovative plan.

Further researches may explore another important aspect of this subject and determine whether the enterprise manufactures modern products, and to what extent products are up-to-date. Such researches may cover the period that matches 
the horizon of long-term planning. Such evaluation should be based on the following scientific, technical and production indicators:

- operational importance and significance of a set (specimen) of knowledge-intensive and high-technological goods and services that describe the innovative level of social, economic, scientific and technological goals and real contribution to effective achievement of the goals;

- the level at which brand-new and innovative S\&T solutions are used;

- the extent to which technological details of the products meet operational, tactical and technological requirements, and the level of advanced foreign analogues;

- the ability of industrial enterprises to launch a commercial production of the set of goods/services and components.

Whereas it is necessary to resolve and eliminate the inconsistency between the deterministic approach to planning the development of the knowledge-intensive and high-tech segment and the increasing uncertainty in the process of supplying economic resources for scientific, technological, production, socio-economic strategies, there should be a new concept. The substance of the new concept implies that the performance of respective plans should be managed by identifying and mitigating the risks caused by multiple technological, production and financial factors. The economic aspect of the process requires to mitigate and compensate for consequences of unfavorable events preventing the enterprise from the effective solution of its tasks. The economic function will help to avoid unreasonable consumption of various resources and funds if the enterprise fails to avert the unfavorable event.

In developing models and methods for evaluating the reliability of knowledge-intensive and high-tech enterprises, we analyzed, systematized and summarized methodological and organizational frameworks and tools used in Russia and abroad for addressing the objective. As a result, the existing Russian and foreign researches were found to be incoherent and consider separate aspects of the science-intensive and high-tech enterprise's performance. Although various methods are used to plan the development of the science-intensive and high-tech industry, there is not yet a consistent and systemic approach to applying the entire array of traditional evaluation methods.

The proposed methodological framework allows to determine the enterprise's reliability when unbiased information is scarce (unavailable) or difficult (forbidden) to access.

\section{Figure 1}

A ranging (interval) function to distribute the analyzed enterprises by reliability

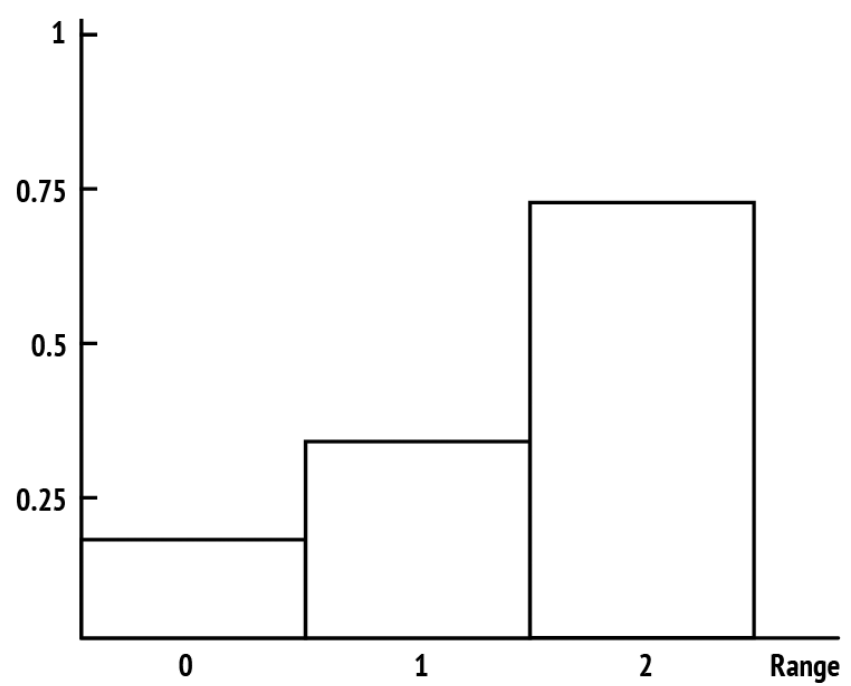

Source:Authoring 


\section{Acknowledgments}

The article was supported by the Russian Foundation for Basic Research, grant No. 16-06-00018, Mathematical and Logical-Linguistic Modeling of Organizational and Economic Mechanisms to Reduce and Compensate for Risk of Innovative Projects for Creating High-Tech Products with a Long Life Cycle: The Rocket-and-Space Technology Case.

\section{References}

1. Kachalov R.M. Upravlenie ekonomicheskim riskom: teoreticheskie osnovy i prilozheniya [Management of economic risk: Theoretical framework and applications]. Moscow, St. Petersburg, Nestor-Istoriya Publ., 2012, 248 p.

2. Slavyanov A.S. [Evaluating the efficiency of methods for economic protection of investment in innovative space projects]. Kontrolling = Controlling, 2013, no. 2, pp. 35-47. (In Russ.)

3. Vilenskii P.L., Livshits V.N., Smolyak S.A. Otsenka effektivnosti investitsionnykh proektov [Evaluating the efficiency of investment projects]. Moscow, Poli Print Servis Publ., 2015, 1300 p.

4. Bohnert A., Gatzert N., Jorgense P.L. On the Management of Life Insurance Company Risk by Strategic Choice of Product Mix, Investment Strategy and Surplus Appropriation Schemes. Insurance: Mathematics and Economics, 2015, vol. 60, pp. 83-97. doi: 10.1016/j.insmatheco.2014.11.003

5. Gerasimov V.V., Pyatykh N.V., Labutin E.S. [Economically viable forms of enterprise reorganization]. Trudy Novosibirskogo gosudarstvennogo arkhitekturno-stroitel'nogo universiteta (Sibstrin) = Bulletin of Novosibirsk State University of Architecture and Civil Engineering (Sibstrin), 2014, vol. 17, no. 57, pp. 69-76. (In Russ.)

6. Morris A.S., Langari R. Measurement and Instrumentation: Theory and Application. Academic Press, 2015, $726 \mathrm{p}$.

7. Glazyrin M.V. Sotsial'no-proizvodstvennyi kompleks - sistemnaya osnova modernizatsii i samorazvitiya [Socio-industrial complex as a system basis of modernization and self-development]. Moscow, Nauka Publ., 2012, $311 \mathrm{p}$.

8. Platon V., Frone S., Constantinescu A. Financial and Economic Risks to Public Projects. Procedia Economics and Finance, 2014, vol. 8, pp. 204-210.

9. Zheglova N.V. [Economic reliability of industrial enterprise: Information support]. Aktual'nye voprosy ekonomicheskikh nauk = Topical Issues of Economic Sciences, 2015, no. 4, pp. 248-255. (In Russ.)

10. Razova E.O. [Enterprise management and its reliability]. Ekonomika i upravlenie: analiz tendentsii i perspektiv razvitiya = Economics and Management: Analysis of Tendencies and Prospects for Development, 2013, no. 8, pp. 257-260. (In Russ.)

11. Burenok V.M., Lavrinov G.A., Podol'skii A.G. Otsenka stoimostnykh pokazatelei vysokotekhnologichnoi produktsii [Estimation of cost indexes of high-tech products]. Moscow, Granitsa Publ., 2012, 423 p.

12. Putyatina L.M., Putyatin A.E. [Financial and economic reliability of enterprises under the Russian economy]. Nauchnye trudy (Vestnik MATI) = Vestnik of Moscow State Aviation Technology Institute (MATI), 2013, no. 21, pp. 311-314. (In Russ.)

13. Kleiner G.B. Strategiya predpriyatiya [Company strategy]. Moscow, Delo Publ., 2008, 568 p.

14. Avdonin B.N., Strel'nikova I.A., Khrustalev E.Yu. [Mechanisms of risk mitigation in hi-tech product manufacture]. Audit i finansovyi analiz = Audit and Financial Analysis, 2011, no. 5, pp. 226-243. (In Russ.)

15. Bertoni F., Croce A., Guerini M. Venture Capital and the Investment Curve of Young High-Tech Companies. Journal of Corporate Finance, 2015, vol. 35, pp. 159-176.

16. Liu P., Zhang X., Liu W. A Risk Evaluation Method for the High-Tech Project Investment Based on Uncertain Linguistic Variables. Technological Forecasting and Social Change, 2011, vol. 78, iss. 1, pp. 40-50.

Please cite this article as: Khrustalev E.Yu., Khrustalev O.E. Model Tools to Assess the Production and Financial Reliability 
17. Elizarova M.I., Khrustalev E.Yu., Khrustalev O.E. [Financial and instrumental methods of risk reduction and compensation when implementing science-driven and high-tech projects]. Audit i finansovyi analiz = Audit and Financial Analysis, 2015, no. 5, pp. 76-82. (In Russ.)

18. Khrustalev E.Yu., Elizarova M.I., Slavyanov A.S. [Production risks and economic danger of modern high-tech industries]. Politematicheskii setevoi elektronnyi nauchnyi zhurnal KubGAU, 2016, no. 3. (In Russ.)

Available at: http://ej.kubagro.ru/2016/03/pdf/19.pdf

19. Altman E., Caouette J., Narayanan P., Nimmo R. Managing Credit Risk: The Great Challenge for Global Financial Markets. New Jersey, John Wiley and Sons, 2008, 628 p.

20. Bragg S.M. Financial Analysis: A Business Decision Guide. Colorado, Accounting Tools Inc., 2014,342 p.

\section{Conflict-of-interest notification}

We, the authors of this article, bindingly and explicitly declare of the partial and total lack of actual or potential conflict of interest with any other third party whatsoever, which may arise as a result of the publication of this article. This statement relates to the study, data collection and interpretation, writing and preparation of the article, and the decision to submit the manuscript for publication. 